\title{
LACTANTIUS AND "RESSOURCEMENT": GOING TO THE SOURCES OF RELIGIOUS LIBERTY IN THE CIVIC ORDER
}

There has been much recent scholarship dedicated to the interpretation of the Catholic doctrine of religious liberty as defined by the Second Vatican Council ${ }^{1}$ in the Declaration Dignitatis humanae $(1965)^{2}$. This academic discussion centers on whether the doctrine of religious liberty is congruent with the Catholic magisterial teaching of the years leading up to the Council; more specifically, with Pope Pius IX's Quanta cura (1864) and Pope Leo XIII's Libertas (1888). This scholarly trajectory has spent great energy on examining whether or not Dignitatis humanae does what it says it does, i.e. "leaves intact the traditional Catholic teaching on the moral duty of the person and society with respect to true religion and the one Church of Christ" 3 , while at the same time affirming that "the human person has a right to religious liberty". Relatively little attention has been paid, however, to the claim made in Dignitatis humanae that the doctrine of religious liberty which it defines has its origin in

*Anthony P. Coleman - M.A., Ph.D. candidate in Boston College; Assistant Professor of Theology at St. Gregory's University in Shawnee, Oklahoma, USA; email: acoleman@sjcme.edu.

${ }^{1}$ Cf. Concilium Vaticanum II, Declaratio de libertate religiosa "Dignitatis humanae", in: Decrees of the Ecumenical Councils, vol. 2: Trent to Vatican II, ed. N. Tanner, Washington 1990, 10011011. Latin quotations given in this paper have been slightly altered from the original text for the benefit of readability [e.g., "v" = "u," "j" = "i"]. All translations are the author's own.

${ }^{2}$ See, inter alia: A. Dulles, "Dignitatis humanae" and the Development of Christian Doctrine, in: Catholicism and Religious Freedom, ed. K.R. Grasso - L.P. Hunt, Lanham 2006, 43-67; F. Russell Hittinger, The Declaration on Religious Liberty: "Dignitatis humanae", in: Vatican II: Renewal within Tradition, ed. M. Lamb - M. Levering, Oxford 2008, 359-82; T. Pink, What is the Catholic Doctrine of Religious Liberty?, http://www.academia.edu/639061/What_is_the_Catholic_doctrine of_religious_liberty (accessed $15^{\text {th }}$ of July 2014); M. Rhonheimer, Benedict XVI's "Hermeneutic of Reform" and Religious Freedom, NV 9 (2011) 1029-1054.

${ }^{3}$ Concilium Vaticanum II, Declaratio de libertate religiosa "Dignitatis humanae" 1: "integram relinquit traditionalem doctrinam catholicam de morali hominum ac societatum officio erga veram religionem et unicam Christi Ecclesiam".

${ }^{4}$ Ibidem 2: "personam humanam jus habere ad libertatem religiosam". 
"the extraordinary catholic teaching, $[\ldots]$ constantly preached bythe Fathers [of the Church], that the person believing in God must respond voluntarily"s.

Pope Benedict XVI went even further in maintaining the link between the doctrine of religious liberty and this teaching of the early Church by stating that Dignitatis humanae "recovered anew the deepest patrimony of the Church" ". The goal of this paper, therefore, is to examine the arguments for religious liberty made by one of its earliest advocates, the early Christian apologist Lactantius ${ }^{7}$, and to demonstrate the influence of his theology on the Church's magisterial teaching concerning religious liberty. This paper concludes by affirming that the Church's use of Lactantius' thought in this regard is an instance of authentic "ressourcement".

1. Lactantius' arguments for Religious Liberty. Lactantius was not the first author to broach the subject of religious liberty. While previous apologists sought to undermine the cult of the pantheon by denying the existence of the gods, or threatening divine judgment upon the persecutors of Christianity, Tertullian was the first author to write of libertas religionis ${ }^{8}$ as an humani juris et naturalis potestatis ${ }^{9}$. Tertullian's treatment of the subject, however, is brief and cursory. In his Apologeticum, the North African apologist argues that it would be an act of irreligion to deny Christians religious liberty because no being, human or divine, would wish to be paid homage against the will of the suppliant ${ }^{10}$. The Roman government has acknowledged this fact by allowing their subject nations to worship their own gods ${ }^{11}$; including the Jewish people ${ }^{12}$. Elsewhere Tertullian states that worshipping according to one's own conviction is a "human right" (humanum jus). He argues that the gods would only be satisfied with a compelled act of religion if "contentiousness" (con-

${ }^{5}$ Ibidem 10: "ex praecipuis doctrinae catholicae, [...] a Patribus constanter praedicatum, hominem debere Deo voluntarie respondere credendo".

${ }^{6}$ Benedictus XVI, Ad Romanum Curiam ob omina natalicia, AAS 98 (2006) 50: "Ha ripreso nuovamente il patrimonio più profondo della Chiesa". See also Discorso del Cardinale Tarcisio Bertone su "La libertà religiosa pietra miliare della nuova Europa" (19 ottobre, 2007), http://www.vatican. va/roman_curia/secretariat_state/card-bertone/2007/documents/rc_seg-st_20071019_fond-paolo-vi_ it.html (accessed $15^{\text {th }}$ of July 2014).

${ }^{7}$ The Latin editions of the texts used in this paper are: Lactantius, Divinarum Institutionum libri septem, fasc. 2: Libri III et IV, ed. E. Heck - A. Wlosok, Berlin 2007; idem, Divinarum Institutionum libri septem, fasc. 3: Libri V et VI, ed. E. Heck - A. Wlosok, Berlin 2009; idem, Epitome Divinarum Institutionum, ed. E. Heck - A. Wlosok, Leipzig 1994. Latin quotations given in this paper have been slightly altered from the original text for the benefit of readability [e.g., "v" = "u," "j" = "i"]. All translations are the author's own.

${ }^{8} \mathrm{Cf}$. Tertullianus, Apologeticum 24, 6 .

${ }^{9} \mathrm{Cf}$. idem, Ad Scapulam 2, 2. For an excellent survey on this topic see P. Garnsey, Religious Toleration in Classical Antiquity, in: Persecution and Toleration, ed. W.J. Sheils, Padstow 1984, 1-27.

${ }^{10} \mathrm{Cf}$. Tertullianus, Apologeticum 24, 6.

${ }^{11}$ Cf. ibidem 24, 7-9.

${ }^{12}$ Cf. ibidem 21, 1. 
tensiosus) were somehow part of the divine nature; which obviously it is not. Thus, one should be lead to religion "voluntarily" (sponte) and not by force ${ }^{13}$. While certainly breaking new ground conceptually, the North African apologist does little more than hint at arguments which will be developed in a more robust fashion by later authors.

Approximately a century after Tertullian, the North African rhetorician Lactantius will take up his mantle in defense of religious liberty and become the first author to expound on this topic in a lengthy and sustained manner albeit one which is highly rhetorical rather than systematic. That Lactantius was aware of Tertullian's position on religious liberty can hardly be doubted. Lactantius includes Tertullian in his review of previous Latin-speaking apologists $^{14}$ and contrasts his own work in the Institutiones with what Tertullian achieved in the Apologeticum ${ }^{15}$. There are also numerous passages in the Institutiones where dependence upon Tertullian's work is evident ${ }^{16}$.

Elaborating on the work of Tertullian as regards religious liberty was made all the more necessary for Lactantius by Diocletain's first rescript of persecution against the Christians from Nicomedia on the Roman feast of the terminalia, the $23^{\text {rd }}$ of February $303^{17}$. At that time Lactantius was in Nicomedia, having been appointed a professor of Latin rhetoric there by Diocletian between 299 and 302. He also was present at the public concilium which Diocletian summoned in order to debate and determine the most prudent course of imperial action in relation to the "Christian question". Lactantius states that at this event not all of the participants were acrimonious to the plight of Christians but acquiesced to the majority out of fear ${ }^{18}$. The mockery and disdain which he heard from two critics

${ }^{13}$ Cf. idem, Ad Scapulam 2, 2.

${ }^{14}$ Cf. Lactantius, Divinae Institutiones V 1, 23.

${ }^{15} \mathrm{Cf}$. ibidem V 4, 3 .

${ }^{16}$ On Lactantius' Logos Christology (cf. Divinae Institutiones IV 8, 6; IV 9, 1), for example, see Tertullianus, Adversus Praxean 5, 3; 7, 6. For a list of references to the work of Tertullian in the Institutiones see Lactantius, Divinarum Institutionum libri septem, fasc. 4: Liber VII, ed. E. Heck A. Wlosok, Berlin 2011, 796.

${ }^{17}$ On nature and consequences of the rescripts of persecution under Diocletian see especially T.D. Barnes, Constantine and Christianity: ancient evidence and modern interpretations, ZACh 2 (1998) 274-294; G.E.M. de Ste Croix, Aspects of the "Great” Persecution, HTR 47 (1954) 75-113. It should also be kept in mind that Diocletian's desire for religious uniformity did not confine itself to the proscription of Christianity. Consider also his anti-Manichean rescript of the $31^{\text {st }}$ of March 302 .

${ }^{18}$ Cf. Lactantius, De mortibus persecutorum 11, 6. This may be an allusion to Constantine. The future emperor was in Nicomedia prior to 306 and may very well have been one of Lactantius' pupils. Even if Constantine was not a formal student of Lactantius at Nicomedia, however, the two certainly met there. This explains Lactantius' later appointment to tutor Constantine's eldest son Crispus at Trier. Cf. H. Drobner, The Fathers of the Church, Peabody 2007, 182; K.H. Schwarte, Lactantius, in: Dictionary of Early Christian Literature, ed. S. Döpp - W. Geerlings, New York 2000, 366; A. Wlosok, Lactance, in: Nouvelle Histoire de la Littérature Latine, vol. 5, ed. R. Herzog - P.L. Schmidt, Turnhout 1993, 428. Lactantius also provides us with the earliest and only Latin edition of the so-called "Edict of Milan"; see Lactantius, De mortibus persecutorum 48, 2-12. 
in particular prompted Lactantius to write his grand Christian apology, the Divinae Institutiones, "so that I might overthrow in one attack all [the accusers of justice] everywhere who are writing or who will have written"19. The following arguments for religious liberty, therefore, are to be found in Lactantius' Institutiones, as well as its abridged companion piece, the Epitome.

Argument 1: persecution is redundant. Divine providence is certainly an attribute of the divine nature. Part of divine providence is reproving sinners in this life, and judging them in the next. If the gods of the pantheon are truly divine beings, then there is no need to persecute those who do not venerate them; for, as divine beings, they will chasten the impious in this life, and punish them in the next. "No one has impunity who has injured God"20. The persecution of Christians by the Roman authorities is, therefore, an unnecessarily redundant action ${ }^{21}$.

Argument 2: the moral argument. Religion is something which, by its very nature as a part of the virtue of justice, is a good. One cannot promote a good through evil means without sullying the good which one seeks to foster. Therefore, since the torture and killing of innocent human life is evil, religious persecution nullifies the good contained in religion" ${ }^{22}$."Butchery and piety are very different things. Truth cannot be joined to force, nor justice to cruelty" 23 . The persecutors, according to Lactantius, are correct in their view that religion is of the utmost importance and even worth the cost of human life. But the good of religion is not proved by one's willingness to kill for its propagation. Rather, the good of religion is demonstrated by one's willingness to die for its defense ${ }^{24}$. "The former are evils, the latter goods; and religion needs to be turned towards the good, not the evil" 25 .

${ }^{19}$ Lactantius, Divinae Institutiones V 4, 1: “accusatores justitiae [...] ut omnes, qui ubique idem operis efficiunt aut effecerunt, uno semel impetu profligarem". These two critics, who go unnamed in Lactantius' text, were Sossianus Hierocles (ibidem V 2, 12-17), onetime governor of Bithynia, and the philosopher Porphyry of Tyre (ibidem V 2, 1-11). The identity of the later has only recently received scholarly consensus due to the outstanding work of Elizabeth DePalma Digeser. Cf. E. DePalma Digeser, Lactantius, Porphyry, and the Debate over Religious Toleration, JRS 88 (1998) 129-146; idem, The Making of a Christian Empire, Ithaca 2000, 93-107; J.M. Schott, Christianity, Empire, and the Making of Religion in Late Antiquity, Philadelphia 2008, 177-185.

${ }^{20}$ Lactantius, Epitome Divinarum Institutionum 48, 5: "nec ullus habuit impune, quod deum laesit". Following this line of argumentation, Lactantius believes that coercing sacrifice to the gods is evidence that the persecuting authorities do not, in fact, believe in their gods. Cf. idem, Divinae Institutiones V 20, 9-11.

${ }^{21} \mathrm{Cf}$. idem, Epitome Divinarum Institutionum 48, 1-6.

${ }^{22}$ Cf. idem, Divinae Institutiones V 19, 21-23.

${ }^{23}$ Ibidem V 19, 17: "Longe diversa sunt carnificina et pietas nec potest aut veritas cum vi aut justitia cum crudelitate conjungi".

${ }^{24}$ Cf. ibidem V 19, 21-22.

${ }^{25}$ Ibidem 5, 19, 22: "Illa enim malorum sunt, haec bonorum, et necesse est bonum in religione versari, non malum”. Cf. ibidem V 20, 11. 
Argument 3: against human benefit. Forced sacrifice does not benefit the suppliant because coercive acts are considered, by their very nature, evil rather than good by the person whom they affect. "Obviously, that to which the will is not inclined, but is recalcitrantly drawn, is evil" 26 . A gift must be measured, according to Lactantius, not just by the giver but also by the receiver. If the recipient deems the gift to be a curse, rather than a blessing, then it is no gift ${ }^{27}$. Naturally, the retort to this argument is that forced sacrifice is for the good of the individual coerced and that, like many virtues, proper worship must be inculcated in an individual by force if necessary. If this were the case however, responds Lactantius, then it seems a strange contradiction in motive that the penalties for unwillingness to sacrifice should be torture and death. How is the good of the individual served by such punishments? ${ }^{28}$ Since, therefore, it is clear that the good of the individual is not the motive behind forced sacrifice then the suppliant's wishes ought to be respected.

Argument 4: against divine benefit. This argument, as we have seen, is taken from Tertullian. Lactantius argues that, just as forced sacrifice fails to benefit the suppliant, so too it fails to benefit the gods. A religious act which is compelled cannot be considered an "acceptable sacrifice" (acceptabile sacrificum $)^{29}$. No one, including the gods, would be satisfied with an act of homage paid by the use of compulsion ${ }^{30}$. "That which is made unwillingly is no sacrifice" 31 . Therefore, forced acts of worship cannot benefit the gods. Further, if the gods are placated by acts of religion which are coerced and extorted through violent means, then they are not worthy of veneration ${ }^{32}$.

Argument 5: based on the nature of religion. The most resonant and influential argument which Lactantius makes for religious liberty flows from a statement given in the previous argument. The statement in questions is "that which is made unwillingly is no sacrifice" ${ }^{33}$. A similar aphorism is given elsewhere in the Institutiones: "that which is poured out reluctantly is no blessing" ${ }^{\prime 34}$. Lactantius explains the meaning behind these maxims by asserting that the practice of the virtue of religion demands a certain amount of freedom. This freedom is necessary in order to ensure that the will is not constrained:

${ }^{26}$ Idem, Epitome Divinarum Institutionum 48, 7: "Unde apparet malum esse illud, ad quod non inlicis volentem, sed trahis recusantem".

${ }^{27} \mathrm{Cf}$. ibidem $48,8-11$.

${ }^{28}$ Cf. idem, Divinae Institutiones V 20, 6.

${ }^{29}$ Idem, Epitome Divinarum Institutionum 48, 6.

${ }^{30} \mathrm{Cf}$. ibidem 48, 7.

${ }^{31}$ Idem, Divinae Institutiones V 20, 7: "At non est sacrificium quod exprimitur invito". Cf. ibidem V 20, 5; Tertullianus, Ad Scapulam 2, 2.

${ }^{32}$ Cf. Lactantius, Divinae Institutiones V 20, 7-8.

${ }^{33}$ Ibidem.

${ }^{34}$ Ibidem V 20, 5: “At non est beneficium quod ingeritur recusanti”. 
"There is nothing so much a matter of freewill as religion. If a soul making a sacrifice is averse to it then it is now nullified, now nothing" ${ }^{\prime 35}$.

Stated systematically, Lactantius' argument is that religion is the virtue of returning to God what is his due. It is the practice whereby the suppliant acknowledges in thought, word, and deed the "bond" (religatum) which exists between God and the human person. Since the practice of this virtue is an act of the will, then the will must have sufficient freedom from external coercion in order to act. Thus, forced acts of religion are not, properly speaking, acts of religion at all.

"But it is religion alone in which liberty has established a home; for, above all else, it is a matter of freewill. Nor can it be imposed by necessity upon anyone, so that one might worship what one does not wish. It can perhaps be simulated by someone, but it cannot be willed"36.

In short, Lactantius is asserting that if there is no freedom of the will, there is no religious act. It is this argument for religious liberty, based on the nature of religion itself, which Lactantius is the first to articulate and the one which the magisterium of the Church will cite in defining the doctrine of religious liberty.

But before we move on to more recent documents, there are two items in particular worth noting about this argument for religious liberty. The first is Lactantius' idea of religion. In true Roman fashion, Lactantius conceives of religion as that aspect of the virtue of justice which deals with matters divine, another name for which is piety (pietas) ${ }^{37}$. Lactantius traces the etymology of the word religio to the verb religare, "to bind or fasten", because humankind is bound to God by the virtue of piety ${ }^{38}$. Vera religio, according to Lactantius, comes from the pairing of true wisdom with true worship. Just as true wisdom is in knowing God's unity, true worship demonstrates this knowledge by loving God as "Father" (pater) and fearing him as "Lord" (dominus) $)^{39}$. Wisdom

${ }^{35}$ Ibidem V 19, 23: "Nihil est enim tam voluntarium quam religio, in qua si animus sacrificantis aversus est, jam sublata, jam nulla est".

${ }^{36}$ Idem, Epitome Divinarum Institutionum 49, 1: "Atquin religio sola est, in qua libertas domicilium collocavit. (2) Res est enim praeter ceteras voluntaria nec imponi cuiquam necessitas potest, ut colat quod non vult. Potest aliquis forsitan simulare, non potest velle".

${ }^{37}$ Piety, or religion, is the virtue which governs the human person's relationship to God. Similarly, fairness, or equity, governs the human person's relationship with other people. Cf. idem, Divinae Institutiones V 14, 9.11-20; Cicero, De inventione 2, 66.

${ }^{38} \mathrm{Cf}$. Lactantius, Divinae Institutiones IV 28, 3; IV 12. This etymological reading of religio directly conflicts with the explanation provided by Cicero, who derives religione from relegere, "to re-read" (ibidem IV 28, 4-5; quot. Cicero, De natura deorum 2, 71-72). St. Augustine agrees with Lactantius' etymology (Augustinus, De vera religione 55, 111; idem, Retractationes I 13, 9), though he is also aware of Cicero's interpretation (Augustinus, De civitate Dei X 3; idem, Retractationes I 13, 9).

${ }^{39}$ The theme of God as dominus et pater appears in Tertullian (cf. Apologeticum 34), but is developed extensively by Lactantius. Cf. E. DePalma Digeser, Lactantius and Constantine's Letter to Arles: Dating the “Divine Institutes”, JECS 2 (1994) 36-37; A. Wlosok, Laktanz und die philoso- 
and worship, therefore, are inextricably linked. They cannot be divided since wisdom is related to worship as knowing is to doing. The pair are united therefore in returning to God what is owed him ${ }^{40}$. Just as creation flows from God's gratuitous act of self-giving, the human person returns to God what is his due by "apprehending" his unity and "offering" him love and obedience. This exitus-reditus cycle is the very pattern of religion for Lactantius.

"This is the condition of our birth, that we might offer just and deserving obedience to the God who created us, that we might acknowledge and follow him alone. We are tied and bound by this chain of piety to God; from whence the term religion received its name" ${ }^{41}$.

To love God as a Father and obey him as Lord is to fulfill the relationship whereby the human person is joined to God by virtue of being a rational creature; i.e., a creature endowed with the capacity to know and worship him:

"Because God has bound the human person to himself and tied it to piety, it is necessary for us to serve him as Lord and obey him as Father" ${ }^{\prime 42}$.

A second point worth noting is the effect Lactantius' understanding of religion has on the role of the will. Because the apologist sees religion exclusively through the lens of virtue, the practice of religion - like that of all the virtues - is dependent upon the disposition of the intellect and will. Thus, when Lactantius addresses the issue of religious liberty the language of "willing" is ubiquitous:

"Religion is not the work of force and injury because it cannot be compelled. It is a thing to be done by words rather than blows, so that there might be freewill" ${ }^{\prime 3}$.

phische Gnosis, Heidelberg 1960, 232-246. This motif appears throughout Lactantius' works in his discussions of God's unity (Lactantius, Divinae Institutiones I 6, 4; I 7, 3; idem, Epitome Divinarum Institutionum 2, 2), religion (idem, Divinae Institutiones IV 3, 13; idem, Epitome Divinarum Institutionum 36, 3), justice (idem, Divinae Institutiones V 18, 14; idem, Epitome Divinarum Institutionum 51, 1; 54, 4), repentance (idem, Divinae Institutiones VI 24, 4), and providence (ibidem II 27, 5).

${ }^{40}$ Cf. Lactantius, Divinae Institutiones IV 4, 3.

${ }^{41}$ Ibidem IV 28, 2: "Hac enim condicione gignimur, ut generanti nos deo justa et debita obsequia praebeamus, hunc solum noverimus, hunc sequamur. (3) Hoc vinculo pietatis obstricti Deo et religati sumus, unde ipsa religio nomen accepit" (emphasis added).

${ }^{42}$ Ibidem IV 28, 12: "quod hominem sibi Deus religaverit et pietate constrinxerit, quia servire nos ei ut domino et obsequi ut patri necesse est" (emphasis added).

${ }^{43}$ Ibidem V 19, 11: "Non est opus vi et injuria, quia religio cogi non potest, verbis potius quam verberibus res agenda est, ut sit voluntas" (emphasis added). What the author has in mind is the repeated appearance of words derived from the verb velle ("to wish or will"), including the noun voluntas ("will or freewill"). Cf. ibidem V 19, 10; V 20, 6-10; idem, Epitome Divinarum Institutionum 48, 10; 49, 2-4. Similarly, the so-called "Edict of Milan" speaks of following the religion "one wishes/wills" (volvisset) with "free minds" (liberis mentibus) (idem, De mortibus persecutorum 48, 2-3). 
By viewing religion "solely" from within the context of virtue, Lactantius is able to exclude from its definition anything which might conflict with the will of the believer. Thus, freedom of the will becomes a sine qua non of religion. In this way, the apologist is able to combat any rival notion of religion which views it in wider terms; terms which may allow for coercion in order to fulfill its civic obligations ${ }^{44}$. In short, freedom of the will is a necessity in matters religious because of the definition of religion which Lactantius adopts.

2. Lactantius and Magisterial Teaching on Religious Liberty. As mentioned in the opening paragraph, this paper hopes to elucidate some of the traces of Lactantius' thought upon the magisterial teaching of the Church regarding religious liberty. The most obvious place to begin this endeavor is to examine section 10 of Dignitatis humanae. In this portion of the document the Council fathers claim that a source for the doctrine of religious liberty is to be found in the Christian belief that the act of faith must be one which is free.

"A principal from extraordinary catholic teaching, contained in the word of God and constantly preached by the Fathers [of the Church], is that the person believing in God must respond voluntarily; hence no one is to be compelled to embrace the faith unwillingly. The act of faith is by its own nature voluntary $[\ldots]$. Therefore it is entirely consonant with the nature of faith that, in matters religious, any form of coercion by human beings should be excluded" ${ }^{25}$.

Amid a lengthy list of Patristic citations provided by the authors of Dignitatis humanae to support this claim, Lactantius is the first. Indeed, this belief clearly has its origin in Lactantius' argument for religious liberty based on the nature of religion or, what Dignitatis humanae refers to as, "the nature of faith" (indoli fidei). In both cases, religious liberty ought to be affirmed based on the freedom of the will which is necessary in order to perform an act of faith or religion.

Lactantius' influence is not confined, however, to the one portion of Dignitatis humanae which explicitly cites a significant Patristic influence. Chapter

${ }^{44}$ On this topic see especially E. DePalma Digeser, Porphyry, Lactantius, and the Paths to God, StPatr 34 (2001) 521-528. According to Eusebius (Praeparatio evangelica 3, 14; 4, 1), Porphyry divided religion into three categories: historical, treated by the poets; speculative, treated by the philosophers; and political, treated by the laws of particular communities. By placing religion squarely within the confines of virtue, Lactantius is, in effect, refuting Porphyry's understanding of religion.

${ }^{45}$ Concilium Vaticanum II, Declaratio de libertate religiosa "Dignitatis humanae" 10: "Caput est ex praecipuis doctrinae catholicae, in verbo Dei contentum et a Patribus constanter praedicatum, hominem debere Deo voluntarie respondere credendo; invitum proinde neminem esse cogendum ad amplectendam fidem. Etenim actus fidei ipsa sua natura voluntarius est [...]. Indoli ergo fidei plene consonum est ut, in re religiosa, quodvis genus coercitionis ex parte hominum excludatur". Cf. Lactantius, Divinae Institutiones 5, 19. Note also, just as they appeared in Lactantius, the presence of words related to the will (voluntarie, voluntarius) in this passage. For a complete list of the Patristic citations given to support this claim see Tanner, Declaratio, p. 1006-1007. 
1 of Dignitatis humanae elucidates the general principle of religious liberty. While the first argument given for this doctrine is based on "the human person's own dignity" (ipsa dignitate personae humanae), immediately following this account is an understanding of religious liberty based on the nature of religion.

"Therefore [a person] must not be forced so as to act contrary to his conscience. Nor must he be impeded so as not to act according to his conscience, especially in matters religious. For the exercise of religion, by its own nature, consists primarily of voluntary and free internal acts by which the human person directs himself to God. Acts of this kind can be neither commanded nor prohibited by any merely human authority"46

The resonance of this passage with Lactantius' argument for religious liberty - i.e., based on the nature of religion itself - is hardly coincidental. The source which Dignitatis humanae credits for this argument is Pope John XXIII's Pacem in terris, section 14. The first paragraph of section 14 states the following:

"Also counted among human rights is being able to venerate God according to the right standard of one's conscience, and to practice religion privately and publically. For just as Lactantius clearly teaches: «this is the condition of our birth, that we might offer just and deserving obedience to the God who created us, that we might acknowledge and follow him alone. We are tied and bound by this chain of piety to God; from whence the term religion received its name»" $"$ "

What is most interesting about the above quotations from Dignitatis humanae and Pacem in terris is not that the authors of Dignitatis humanae failed to include Lactantius in their citation of Pope John XXIII. Rather, what is most surprising is Pope John XXIII's selection of quotations from Lactantius. Instead of simply quoting a passage which directly addresses the apologist's belief in religious liberty, Pope John selects an excerpt which gets at the heart of Lactantius' thought. In particular, Lactantius' belief that religion is a fundamental part of what it means to be an homo sapiens; a creature endowed with wisdom. By virtue of the gift of wisdom, human beings have the capacity to

\footnotetext{
${ }^{46}$ Concilium Vaticanum II, Declaratio de libertate religiosa "Dignitatis humanae” 3: "Non est ergo cogendus, ut contra suam conscientiam agat. Sed neque impediendus est, quominus juxta suam conscientiam operetur, praesertim in re religiosa. Exercitium namque religionis, ex ipsa ejus indole, consistit imprimus in actibus internis voluntariis et liberis, quibus homo sese ad Deum directe ordinat: hujusmodi actus a potestate mere humana nec imperari nec prohiberi possunt". Cf. Pacem in terris 14.

${ }^{47}$ Pope John XXIII, Pacem in terris, AAS 55 (1963) 260-261: "In hominis juribus hoc quoque numerandum est, ut et Deum, ad rectam conscientiae suae normam, venerari possit, et religionem privatim publice profiteri. Etenim, quemadmodum praeclare docet Lactantius, «hac condicione gignimur, ut generanti nos Deo justa et debita obsequia praebeamus, hunc solum noverimus, hunc sequamur. Hoc vinculo pietatis obstricti Deo et religati sumus, unde ipsa religio nomen accepit»". Quot. Lactantius, Divinae Institutiones IV 28, 2.
} 
know and worship God. To prevent a human being from practicing religion, or to compel him to do so against his will, is therefore to interrupt, or disintegrate, the one movement of piety. It is to prevent the human person from being most fully human. Thus, not only was Pope John returning to the sources of religious liberty by quoting Lactantius, he was returning to the very core of Lactantius' theology. In this regard, both Dignitatis humanae and Pacem in terris adopt Lactantius' concept of religion as a virtue in order to define the doctrine of religious liberty. In the words of Dignitatis humanae: religion is that which "consists primarily of voluntary and free internal acts by which the human person directs himself to God"48.

$$
* * *
$$

As its title would suggest, the most prominent argument for religious liberty made in Dignitatis humanae is one based on the inherent dignity of the human person; the depths of which the Church has come to understand, and continues to understand, over time ${ }^{49}$. While acknowledging that divine revelation does not expressly affirm the right to religious liberty, Dignitatis humanae states that "nevertheless it reveals the dignity of the human person in all its fullness" $" 50$. Thus, the Council affirms that, to a certain degree, the defining of the doctrine of religious liberty is an example of what Cardinal Newman referred to as the development of Christian doctrine ${ }^{51}$. Further, and as stated above, the scholarly trajectory on this subject has tended to focus on whether or not this teaching truly meets the criteria of doctrinal development. From both the magisterial and academic perspectives, then, the doctrine of religious liberty is viewed as an example of "aggiornamento"; of the Church bringing her teaching up-to-date by applying the truths found in divine revelation to the ever-changing circumstances of the world.

But there is another aspect of the doctrine of religious liberty which the authors of Dignitatis humanae do not attribute to the development of doctrine. The argument for religious liberty based on the nature of religion also is cited by the fathers of the Council in support of this doctrine. This argument has its origins in the early Church and was first developed at length by the apologist Lactantius. By drawing from the works of Lactantius, therefore, the magisterium has gone back to the sources of the doctrine of religious liberty. Thus, there

${ }^{48}$ Concilium Vaticanum II, Declaratio de libertate religiosa "Dignitatis humanae” 3: "consistit imprimus in actibus internis voluntariis et liberis, quibus homo sese ad Deum directe ordinat".

${ }^{49}$ Cf. ibidem 1, 9 .

${ }^{50}$ Ibidem 9: "tamen humanae personae dignitatem in tota ejus amplitudine patefacit".

${ }^{51}$ Cf. J.H. Newman, An Essay on the Development of Christian Doctrine, South Bend 1989. This is precisely Cardinal Dulles' argument in Dignitatis humanae and the Development of Christian Doctrine. See footnote 2. 
is an aspect to the Church's doctrine of religious liberty which stems from the other of the great twin themes of the Council: "ressourcement".

\section{LAKTANCJUSZ I RESSOURCEMENT: DROGA DO ŹRÓDEŁ WOLNOŚCI RELIGIJNEJ W PORZĄDKU ŚWIECKIM}

\section{(Streszczenie)}

Laktancjusz, jako uznany retor, piastował urzędowe stanowiska w okresie panowania Dioklecjana (284-305) i Konstantyna (306-337). Był również obecny w Nikomedii, gdy zimą roku 302/303, Dioklecjan wezwał do rozwiązania ,problemu chrześcijaństwa”. Szyderstwa i pogarda, które docierały do Laktancjusza, skłoniły go do napisania wielkiej chrześcijańskiej apologii - Divinae Institutiones. Atmosfera prześladowania, która towarzyszyła powstaniu Institutiones bez wątpienia skłoniła apologetę do dyskusji o wolności religijnej, nie tylko jako ogólnym prawie chrześcijan, ale jako podstawowym prawie osoby ludzkiej. Prezentowany artykuł ukazuje argumenty Laktancjusza za wolnością religijną w porządku świeckim oraz dowodzi, że wiara Laktancjusza w potrzebę wolności dokonywania czynności religijnych determinuje jego afirmację wolności religijnej jako takiej. Artykuł analizuje także użycie pism Laktancjusza w katolickiej nauce społecznej i stwierdza, że soborowe nauczanie Kościoła katolickiego na temat wolności religijnej jest przykładem nie tylko rozwoju doktrynalnego, ale autentycznego powrotu do nauczania Ojców.

Key words: Lactantius, apology, religious liberty, Roman Empire.

Słowa kluczowe: Laktancjusz, apologia, wolność religijna, Cesarstwo Rzymskie. 
